\title{
Indigenous arbuscular mycorrhizae in areas with different successional stages at a tropical dry forest biome in Brazil
}

\author{
Fernanda Covacevich ${ }^{1 *}$ and Ricardo L. L. Berbara ${ }^{2}$ \\ ${ }^{1}$ Department of Agronomy, EEA INTA-FCA, UNMP, C.C. 276, Balcarce, Buenos Aires 7620, Argentina. \\ ${ }^{2}$ Department of Soil, Rural Federal University of Río de Janeiro (UFRRJ), BR 465, km 7, \\ CEP 23890-970 Seropédica, RJ, Brazil.
}

Accepted 23 June, 2011

\begin{abstract}
Arbuscular mycorrhizal fungi mycelium creates multiple fungal links between roots of plants and could be an important component of plant succession in ecosystems. Our objective was to compare the spore number (SN), genus contribution and indigenous arbuscular mycorrhizal colonization (AMC) capacity of soils from a tropical dry forest (caatinga) ecosystem in Brazil at different levels of successional stages after culturing for 3 months in a greenhouse Brachiaria decumbens (= Urochloa decumbens Staph) as trap plants. Soil samples were collected from Parque Estadual Mata Seca (Manga, Minas Gerais State, Brazil) in four different areas: (a) Pasture (5 years without human activity, covered mainly by Panicum maximum Jacq.); and three different forest successional stages: (b) Initial (8 years in process of spontaneous recovery), (c) Intermediate (17 years without human activity) and (d) Late (no recorded human activity). At 90 DAP plants growing at intermediate disturbance soil had the lowest dry matter production, probably because of the lowest available soil $\mathbf{P}$ and $\mathrm{Ca}$ contents of this soil. The highest SN was found in soils from pasture while the lowest was in soils from the intermediate area. Glomus was, in general, the most abundant genus followed by Acaulospora, Gigaspora and Scutellospora (always present in intermediates rates). The contribution of Archaeospora was the lowest; however, in some cases it was absent. AMC was higher in plant roots growing in soils from pasture but the lowest AMC was in plant roots from the intermediate area. This could be associated with the soil acidity, Al and $\mathrm{H}$ contents of this area which could be toxic to AMF. Mycorrhiza formation and SN appeared to be more related to the physicochemical characteristics of the soil and the host plant development to the soil successional stage. Further studies are needed in order to identify appropriate management strategies for restoration of altered lands in order to contribute to the biodiversity conservation and microbial activity of ecosystems.
\end{abstract}

Key words: Arbuscular mycorrhizae, plant succession, soil factors.

\section{INTRODUCTION}

There is an emerging consensus that changes occurring aboveground (in the atmosphere or by consequences of

*Corresponding author. E-mail: covac@mdp.edu.ar.

Abbreviations: AMC, Arbuscular mycorrhizal colonization; AMF, arbuscular mycorrhizal fungi; Ar, arbuscule content; DAP, days after planting; SDM, shoot dry matter; SN, spore number. land use) undoubtedly will affect plant, animal and belowground microbial biodiversity and that those compartments are intimately linked (van der Putten et al., 2009). Thus, recent studies are focused to understanding these relationships. Arbuscular mycorrhizal fungi (AMF) are belowground plant symbionts of roots that add another dimension to the plant-soil-microbe system because it can directly and indirectly influence other soil microbes and an adequate soil nutrient cycling. Mycorrhizal fungi are able to develop a symbiotic association with more than $90 \%$ of vascular or 
non-vascular terrestrial plants (van der Heijden et al., 1998; Pongrac et al., 2007; Feddermann et al., 2010). AMF are a diverse taxon, both systematically and functionally and mechanisms governing the formation and maintenance of the symbiosis have not been yet fully clarified. They belong to a monophyletic phylum, the Glomeromycota (Schüßler et al., 2001; Smith and Read, 2008), its taxonomic classification is constantly changing and a new list of families and genera has recently been published (Schüßler and Walker, 2010).

Mycorrhizal symbiosis is usually not host-specific, and displays abundant ecological differentiation and specialization to both their biotic and abiotic environments, including types that are highly specialized to unusual ecological niches (Fitter et al., 2004). AMF form a uniformly distributed mycelium in soil and hyphal proliferation occurs in response to several types of organic material deposition (Rillig and Mummey, 2006), connecting host plants and improving physical and chemical soil quality. The contribution of AMF on plant nutrition is widely documented, specially where available soil $P$ limit plant growth of native plants as well agricultural crops (Menéndez et al., 2001; Covacevich et al., 2006, 2007; Siddiqui et al., 2008; Smith and Read, 2008; Guissou, 2009; Ndiaye et al., 2009). AMF provide other benefits to their host plants, stabilizing soil structure and increasing the tolerance to water stress, soil compaction, salinity and drought, root pathogens and heavy metals or others toxic substances present in the soil (Davies et al., 1993; Augé, 2001; Feng et al., 2002; Trotta et al., 2006; Hildebrandt et al., 2007; Siddiqui and Pichtel, 2008; Raviv, 2010; Miransari, 2011). The high amount of hyphae produced by AMF is correlated with significant increases in the aggregate stability of soils (Jastrow et al., 1998; Tisdall et al., 1997; Rillig, 2004; Treseder and Turner, 2007), modifying the soil's ability to mobilize nutrients, maintaining water content, facilitating roots penetration in soil and diminishing soil erosion potential.

The mycelium of AMF also interconnects the root systems of neighboring plants both of the same as different species (Allen et al., 2003). In this sense, mycorrhizal networks can create indefinitely large numbers of fungal linkages connecting together many plants in a community (Newman, 1988; Giovannetti et al., 2006). Changes in vegetation as a result of environmental changes may affect the spread of native AMF. This suggests that AMF formation could be an important element of plant succession in ecosystems (Bellgard and Williams, 2011). Consequently, AMF presents an increasingly interest for agriculture, agroforestry, altered lands restoration and natural ecosystems conservation. Observations on plant succession patterns in semiarid regions reported that AMF could play an important role in the composition and stability of plant communities. However, there are still no conclusive results on the relationship between mycorrhizal colonization and the spatial heterogeneity of ecosystems (Boerner et al., 1996).
Mycorrhizal fungi have a widespread presence in all environments and especially within the tropics (Fuchs and Haselwandter, 2004; Moreira et al., 2007; Makoi and Ndakidemi, 2009) although most of the knowledge regarding the effect of soil management on mycorrhizae comes from temperate regions (Raviv, 2010). In particular, little is known about the possible relationship between infectivity capacities of native AMF from a dry forest type called "Mata Seca" (in Portuguese), in the caatinga biome. The caatinga is of considerable importance because this type of tropical dry forest is the only biome of exclusively Brazilian distribution (Queiroz, 2006) and an important part of the world's biological richness is found in that ecosystem. The uniqueness and threat level of this vegetation type was reviewed by Espírito-Santo et al. (2009). The objective of this work was to evaluate, under controlled conditions in pots, the spread of indigenous mycorrhization, the contribution of genera and abundance of AMF spores on soils collected from Brazilian Mata Seca ecosystems with different successional stages.

\section{MATERIALS AND METHODS}

\section{Study sites}

Soil samples were collected from the Dry Forest State Park, in the

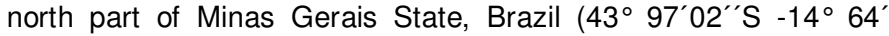
$09^{\prime \prime} \mathrm{W}$ and $44^{\circ} 00^{\prime} 05^{\prime \prime} \mathrm{S}-14^{\circ} 53^{\prime} 08^{\prime \prime} \mathrm{W}$ ). The climate is tropical wet $(\mathrm{Aw})$, the mean annual maximum temperature is $32^{\circ} \mathrm{C}$, annual average $18{ }^{\circ} \mathrm{C}$, annual rainfall is $660 \mathrm{~mm}$ (SIMGE, 2008). The region is characterized by a well marked dry season (May-October; rainfall less than $60 \mathrm{~mm} / \mathrm{month}$, temperature 24 to $26^{\circ} \mathrm{C}$ ). Rains are irregular and concentrated in the summer (December-March).

\section{Soil sampling at field sites and preparation of trap cultures for AMF}

Soil samples (0-10 and $10-20 \mathrm{~cm}$ depth) were collected during the wet season (February, 2008) in a pasture area with 5 years without anthropogenic interference, covered mainly by Panicum maximum (= Urochloa maxima (Jacq.) Webster RD) grasses and in three areas with different stages of plant succession: (a) Initial (area with 8 years of spontaneous regeneration process), (b) Intermediate (area with 17 years without anthropogenic interference) and (c) Late (area without any sign of anthropogenic interference). For each area of study, plots of $1000 \mathrm{~m}^{2}$ were delimited. For each area, soil samples (1500 g each) were collected with five replications. Any individual sample (from each area and depth) was composed by nine subsamples of (0-10 and $10-20 \mathrm{~cm}$ depth). Field soil was sieved through a $1 \mathrm{~cm}$ mesh, large root fragments were cut in pieces of $1 \mathrm{~cm}$, they were returned to the soil and air dried in darkness at $10^{\circ} \mathrm{C}$ until use one month later.

The experiments were conducted at the Embrapa Agrobiologia, Seropédica-Universidade Federal Rural do Río de Janeiro, Seropédica, Rio de Janeiro, Brazil. Trap cultures of AMF in each area were made by using experimental units $(n=60)$ which consisted of white plastic pots of $0.8 \mathrm{~kg}$ (used for plants growing until 45 days after planting-DAP) or $1 \mathrm{~kg}$ (used for plants growing until $90 \mathrm{DAP}$ ). All pots were filled with a substrate composed of not autoclaved homogenized soil from the field and twice autoclaved 
Table 1. Soil characteristics at sites selected from the Dry Forest State Park. OC= organic carbon.

\begin{tabular}{lccccc}
\hline \multirow{2}{*}{ Site } & $\mathbf{p H}$ & $\mathbf{P}$ & $\mathbf{O C}$ & $\mathbf{A l}$ & $\mathbf{H}$ \\
\cline { 2 - 6 } & $\mathbf{( w a t e r})$ & $(\mathbf{m g ~ k g}$ & $\mathbf{1})$ & $\left.\mathbf{g ~ k g}^{-1}\right)$ & \multicolumn{2}{c}{$\left(\mathbf{c m o l}_{\mathbf{c}} \mathbf{~ k g}^{-1}\right)$} \\
\hline Initial & $7.02 \mathrm{a}$ & $0.61 \mathrm{~b}$ & $22.03 \mathrm{a}$ & $<0.00$ & $0.86 \mathrm{~b}$ \\
Intermediate & $5.06 \mathrm{~b}$ & $0.20 \mathrm{~b}$ & $18.01 \mathrm{~b}$ & 0.58 & $3.61 \mathrm{~b}$ \\
Late & $6.62 \mathrm{a}$ & $0.44 \mathrm{~b}$ & $21.90 \mathrm{a}$ & $<0.00$ & $1.92 \mathrm{a}$ \\
Pasture & $6.42 \mathrm{a}$ & $1.87 \mathrm{a}$ & $14.42 \mathrm{~b}$ & $<0.00$ & $1.89 \mathrm{~b}$ \\
\hline
\end{tabular}

Means within the same column followed by the same letter are not significantly different (LSD, $P<0.05)$.

river sand in a proportion of 2:1. The experiment was set up with 5 replications, 4 areas (soil from $0-10 \mathrm{~cm}$ depth of Initial, Intermediate, Late and Pasture areas) and 2 harvest (45 DAP and 90 DAP). Additionally, $0.8 \mathrm{~kg}$ pots were filled with soil from the same areas at 10 to $20 \mathrm{~cm}$ depth with 5 replications and harvested at 45 DAP. To avoid preferences of mycorrhizal infection for a certain host plant, experiment was done using only Braquiaria grasses as host plant in all treatments. Seeds were sterilized with $4 \%$ sodium hypochlorite solution for approximately $5 \mathrm{~min}$, rinsed with distilledautoclaved water, pregerminated in sterile vermiculite and grown in a growth chamber during 5 days. Homogeneous-sized pregerminated plants were planted in pots (4 plants pot $^{-1}$ in 45 DAP pots, and 3 plants pot $^{-1}$ in 90 DAP pots). Plants were grown in glasshouse under natural light conditions, daily watered with distilled water and the substrate was maintained at water holding capacity $(65 \% \mathrm{w} / \mathrm{s})$. Hoagland solution (P $30 \%$ ) was supplied at 30 and 60 DAP.

Trap cultures harvest: Plant growth and mycorrhizal colonization assess

After 45 DAP and 90 DAP plants were harvested from 0.8 and $1 \mathrm{~kg}$ pots, respectively. Shoots were cut and plant material was oven dried at $60^{\circ} \mathrm{C}$ for shoot dry matter (SDM) estimation. As a measure of the infection potential of field samples, initial mycorrhizal root colonization was determined in the trap cultures (Oehl et al., 2004) after 45 and 90 DAP. Root material was washed out free of soil and collected on sieve $(0.5 \mathrm{~mm})$. Immediately, roots were cut into $1 \mathrm{~cm}$ pieces, thoroughly mixed, cleared with $\mathrm{KOH}\left(10 \%, 30 \mathrm{~min}, 90^{\circ} \mathrm{C}\right)$, acidified $(\mathrm{HCl}, 0.1 \mathrm{~N})$, and stained with trypan blue $\left(0.05 \% \mathrm{vol}^{-1}, 5\right.$ min, $\left.100^{\circ} \mathrm{C}\right)$ in lactoglycerol $(1: 1: 1$ lactic acid, glycerol, distilled water) according to the modified method described by Phillips and Hayman (1970). Presence of mycorrhizal infection was assessed by microscopic examination (40X) of the root system. A segment was considered infected if contained hyphae plus arbuscules, coils or vesicles. Mycorrhizal colonization was estimated as AMC (\%) and percentage of arbuscules (Ar) of the root cortex, according to the Trouvelot et al. (1986) method.

\section{AMF spore isolation and identification}

AMF spores of the trap cultures were extracted by wet sieving and sucrose density gradient centrifugation (Daniels and Skipper, 1982). The procedure included passage of $50 \mathrm{~cm}^{3}$ of harvested trap culture substrate through $500,125,53$ and $37 \mu \mathrm{m}$ sieves. The contents of the 125,53 and $37 \mu \mathrm{m}$ sieves were centrifuged at $800 \times$ $\mathrm{g}$ for $3 \mathrm{~min}$, the supernatant was discarded, and the pellet was layered onto a water-sucrose solution (80\% [wt/vol]) gradient and centrifuged at $900 \times \mathrm{g}$ for $2 \mathrm{~min}$. The resulting supernatant was passed through the $37 \mu \mathrm{m}$ sieve, washed with tap water. Quantification of spore number (spores, spore clusters, and sporocarps) was carried out in $9 \mathrm{~cm}$ diameter Petri dishes with a gridline of $1 \mathrm{~cm}$ per side under a stereoscopic microscope at 50X (Lugo and Cabello, 2002). Ten divisions were counted and related to the total spores number (SN) (Schalamuk et al., 2006). Taxonomic identification was made at the Microbiology LaboratoryEstación Experimental Agropecuaria INTA, Balcarce (Argentina). For that, $80 \%$ of spores of each sample were mounted onto slides with the permanent mounting medium for fungi polivinil alcohol PVA (Omar et al., 1979) with or without Melzer's reagent to assist with the identification of AMF spores (Morton, 1988). About $70 \%$ of the spores fixed on slides could be identified at the genus level. Dead and decaying spores, lacking clear morphological features were not included in the number quantification or the genus identification. The spores' identification was based on current species descriptions and identification manuals (Schenck and Pérez, 1990; International Culture Collection of Arbuscular and VesicularArbuscular Mycorrhizal Fungi http://invam.caf.wvu. edu/Myc_Info/Taxonomy/species.htm; Schüßler and Walker, 2010).

\section{Statistical analysis}

Data were analyzed by ANOVA (SAS 9.2 Institute Inc., 2002-2008). Means among treatments were compared with the least significant difference $(L S D)$ test $(P<0.05)$. All presented data are means of untransformed values.

\section{RESULTS AND DISCUSSION}

Soil physicochemical attributes varied significantly among sites (Table 1) and the soil from the Intermediate area was the most different in the quantified characteristics in comparison to the other areas. In that sense, both the most acidic condition and highest $\mathrm{Al}$ and $\mathrm{H}$ contents were found in those samples. Furthermore, the lowest soil $\mathrm{P}$ content was determined at the Intermediate site whereas the highest soil $\mathrm{P}$ was found in the Pasture soil. Initial and Late soils showed the highest organic carbon contents.

The SDM, AMC, Ar and SN significantly varied among the different areas where the soil was collected (Table 2). SDM of Braquiaria was highest in plants growing in intermediate and pasture soils at 45 DAP (Figure 1). However, at 90 DAP plants growing in Intermediate soils showed lowest SDM production. This may be due in part to the lower available soil $\mathrm{P}$ and $\mathrm{Ca}$ content in Intermediate soils, which were two or three times lower than in the other areas, and also to the low $\mathrm{pH}$, which 
Table 2. Analysis of variance of successional areas (SA) and soil depth (SD) on shoot dry matter (SDM) production, arbuscular mycorrhizal colonization (AMC), percentage of arbuscules (Ar) of Braquiaria plants and spore numbers (SN) of soils at 45 days after planting.

\begin{tabular}{cccccc}
\hline Source of variation & Degree of freedom & SDM & AMC & Ar & SN \\
\hline Replications & 4 & 0.09 & 0.74 & 0.83 & 0.01 \\
Successional area (SA) & 3 & 0.05 & 0.01 & 0.10 & $<0.0001$ \\
Soil depth (SD) & 1 & $<0.001$ & $<0.0001$ & $<0.0001$ & 0.41 \\
A×SD & 3 & $<0.01$ & 0.28 & 0.03 & 0.94 \\
\hline
\end{tabular}

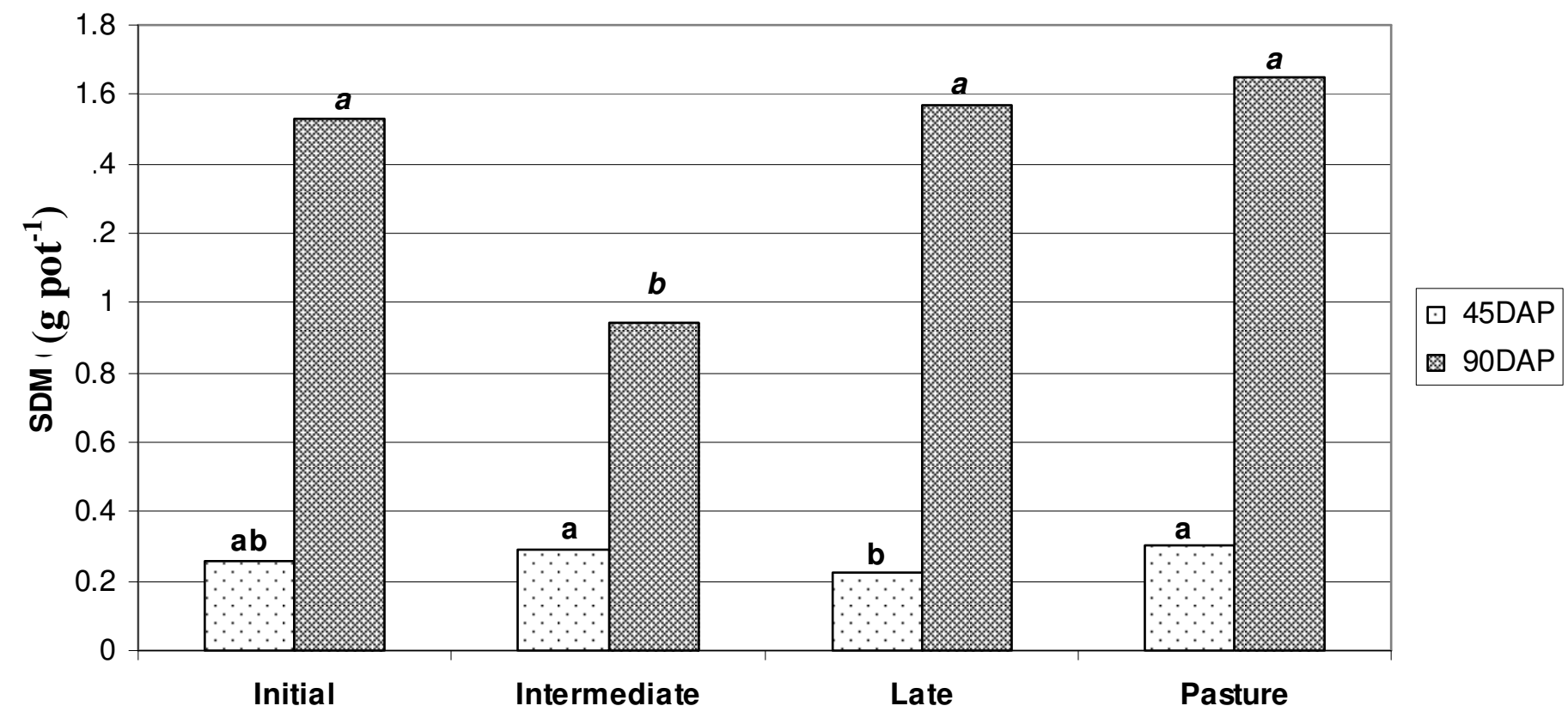

Figure 1. Shoot dry matter production (SDM) of Brachiaria at 45 and 90 days after planting (DAP) growing in soils from different successional ecosystems. For each sampling date (standard letters for 45 DAP, italics for 90 DAP), columns with the same letters show no significant differences in SDM among soils (LSD, $\mathrm{P}<0.05)$.

was about 1.5 times lower than in the other soils. With increasing soil depth, we found decreases in the percentage of roots colonized by AMF and in plant productivity. AMC and $\mathrm{Ar}$ of roots were significantly higher at 45 DAP in pots filled with the field soil of 0 to 10 $\mathrm{cm}$ depth comparing with 10 to $20 \mathrm{~cm}$ depth samples. This could indicate higher soil propagules content in the most superficial soil depth. Also Schwab and Reeves (1981), and Cooke et al. (1993) reported decreases in mycorhizal colonization through soil depth profiles. However, Covacevich et al. (2006) did not found differences in colonization between 0 to 10 and 10 to $20 \mathrm{~cm}$ of soil samples collected in agricultural field grasses of Argentina. On the other hand Neville et al. (2002) found that AM hyphae and total fungal colonization of Populus tremuloides Michx were significantly lower in the top 5 $\mathrm{cm}$ of the soil than in the 5 to $10 \mathrm{~cm}$. Furthermore, at our experiment, the $\mathrm{SN}$ was not significantly different when comparing these 0 to 10 and 10 to 20 soil depths (Table
3). Ohel et al. (2005) found either differences or no differences in the $\mathrm{SN}$ between 0 to 10 and 10 to $20 \mathrm{~cm}$ of a Calcaric Regosol (pH 7, P $10.9 \mathrm{mg} \mathrm{P} \mathrm{kg}^{-1}$ ) and a Haplic Luvisol ( $\mathrm{pH}$ 6.2, $\mathrm{P} 21.8 \mathrm{mg} \mathrm{P} \mathrm{kg}^{-1}$ ) soil samples collected in grassland fields from Upper Rhine Valley (Germany), respectively. It is an indicative that SN and AMF infective propagules are not always well correlated. Some incongruities among results indicate that AMF are differentially partitioned at different soil depths and it could be accounted by extreme differences in propagule richness related to soil characteristics and differences in time of germination of spores of different soil environments. Highest $\mathrm{SN}$ were found in soils from Pasture followed by Initial area while the lowest SN were found in pots with Intermediate area soil (Table 4). Silva Santos Santos (2010) working with field samples collected in the same areas as in this study also found that Pasture had highest SN (about 600 spores $\times 100 \mathrm{~g} \mathrm{soil}^{-1}$ ) followed by the Initial area (about 420 spores $\times 100 \mathrm{~g} \mathrm{soil}^{-1}$ ). 
Table 3. Effect of soil depth on shoot dry matter (SDM) production, arbuscular mycorrhizal colonization (AMC), percentage of arbuscules (Ar) of Braquiaria roots and spore numbers (SN) at 45 days after planting.

\begin{tabular}{|c|c|c|c|c|}
\hline Soil depth (cm) & SDM & AMC & $\mathrm{Ar}$ & SN $\left(\right.$ spores $\left.\times 100 \mathrm{~g} \mathrm{soil}^{-1}\right)$ \\
\hline $0-10$ & $0.308 \mathrm{a}$ & $44.7 \mathrm{a}$ & $30.9 a$ & $87 a$ \\
\hline $10-20$ & $0.232 \mathrm{~b}$ & $25.1 \mathrm{~b}$ & $15.2 \mathrm{~b}$ & $80 \mathrm{a}$ \\
\hline
\end{tabular}

Means within the same column followed by the same letter are not significantly different (LSD, $P<0.05)$.

Table 4. Spore number (SN) and contribution of representative genera of arbuscular mycorrhizal fungi found in soils (0-10 $\mathrm{cm})$ of different successional areas with Braquiaria plants grown until 45 and 90 days after planting (DAP).

\begin{tabular}{|c|c|c|c|c|c|c|c|}
\hline \multirow{2}{*}{ Harvest } & \multirow{2}{*}{ Site } & \multirow{2}{*}{ SN (spores $100 \mathrm{~g} \mathrm{soil}^{-1}$ ) } & \multicolumn{5}{|c|}{ Genera (\%) } \\
\hline & & & Glomus & Acaulospora & Archaeospora & Gigaspora & Scutellospora \\
\hline \multirow[t]{4}{*}{45 DAP } & Initial & $116 \mathrm{~b}$ & 61 & 21 & -- & 8 & 10 \\
\hline & Intermediate & $10 \mathrm{c}$ & 26 & 32 & 2 & 10 & 30 \\
\hline & Late & $51 \mathrm{c}$ & 48 & 36 & -- & 9 & 7 \\
\hline & Pasture & $172 \mathrm{a}$ & 42 & 33 & 5 & 9 & 11 \\
\hline \multirow[t]{4}{*}{90 DAP } & Initial & $133 \mathrm{~b}$ & 52 & 29 & 1 & 9 & 9 \\
\hline & Intermediate & $38 \mathrm{c}$ & 27 & 42 & 1 & 5 & 25 \\
\hline & Late & $95 \mathrm{~b}$ & 41 & 40 & -- & 10 & 9 \\
\hline & Pasture & $237 a$ & 39 & 36 & 4 & 11 & 10 \\
\hline
\end{tabular}

Means within the same DAP followed by the same letter are not significantly different (LSD,P<0.05).

However, the SN quantified at our study was about 3.5 to 6 folds lower than the amounts reported by Silva Santos Santos (2010). In the present study, the lowest SN of soil at the trap culture was found in soils collected at the Intermediate area. Silva Santos (2010) determined that the Late area had the lowest SN under field conditions (about 240 spores $\times 100 \mathrm{~g} \mathrm{soil}^{-1}$ ) and pointed that lowest SN could be an indicative of a highest environmental stability of soils. The most abundant genus was Glomus, followed by Acaulospora that showed the highest frequency in Intermediate soils at 45 and 90 DAP and reached the same proportion of Glomus in Late soils at 90 DAP. Silva Santos (2010) also found that Acaulospora presented the highest frequencies at the Intermediate site under field conditions. The results obtained in the present study are agree with other studies that reports that Acaulospora could be found preferably under moderately acid soil-conditions at $\mathrm{pH}<6.2$ (Stürmer, 1999) and preferably within the range 3.5-5.8 (Trufem, 1995). Interestingly, no spores belonging to the genus Archaeospora were found in the pots filled with the Initial soils at 45 DAP nor in the Late soils during the two harvest of the experiment. When Archaeospora spores were found, their contribution to the total recorded genera was the lowest. Silva Santos (2010) did not found any spores belonging to the Archaeospora at the Late site under field conditions. On the other hand, Gigaspora and Scutellospora were always present at Intermediate rates from 5 to $25 \%$ (Table 4 ).
Silva Santos (2010) analyzed SN and mycorrhizal diversity of soil samples collected in the field. The present paper analyzed $\mathrm{SN}$ and most representative genera from soils collected at the same areas and at the same moment like Silva Santos (2010) in order to establish AMF-trap cultures using Braquiaria as host plants. Although the overall response patterns were similar between our results and those of Silva Santos (2010), some differences were found (for example in the overall amount of the $\mathrm{SN}$ ). Differences between our results in pots and those found by Silva Santos (2010) under field conditions could be attributed to the fact that AMF sporulation varies with host and AMF species and also with growing conditions (affecting fungus directly and indirectly through host physiology). Many studies have demonstrated that not necessarily the same AMF species are found in a field site and in greenhouse cultures with soil from the same site and growing in "trap cultures" (Jansa et al., 2002; Oehl et al., 2003, 2004), although there is usually a considerable overlap between the same species groups. The period of time during the cultures are grown appears to be important. Sporulation often occurs within 3 to 4 weeks after onset of mycorrhizal colonization under almost any conditions except the high availability of soil $\mathrm{P}$, which could depress or inhibits all fungal growth phases (http://invam.caf.wvu.edu/fungi/taxonomy/concepts/lifecy cle.htm). Declerck et al. (2001) found that sporulation under controlled conditions increased from 4 to 5 weeks 


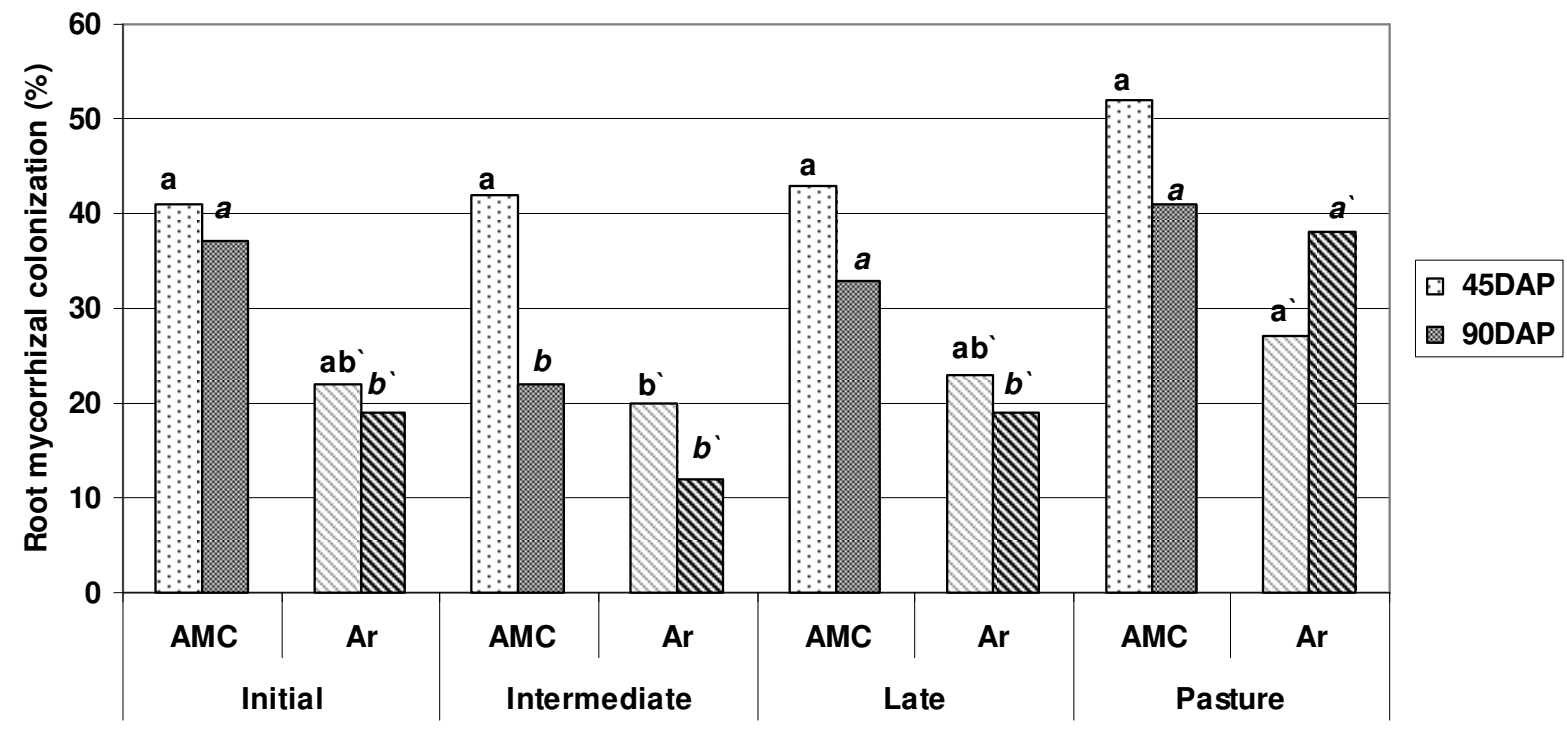

Figure 2. Arbuscular mycorrhizal colonization (AMC) and percentage of arbuscules (Ar) of Brachiaria roots at 45 and 90 days after planting (DAP) grown in soils from different successional ecosystems. For each sampling date (standard letters for $45 \mathrm{DAP}$, italics for $90 \mathrm{DAP}$ ) and value of root mycorrhizal colonization (without apostrophe for AMC, with apostrophe for Ar) columns with the same letters show no significant differences in mycorrhizal colonization among soils (LSD, $\mathrm{P}<0.05)$.

to approximately 10 weeks; at this time sporulation was stabilized. Oehl et al. (2004) found that there is a wide time range (4 to 20 months) in which AMF could sporuLate.

Mycorrhizal development of Braquiaria roots decreased from 45 to 90 DAP (Figure 2). It is likely that most of the photosynthates were allocated in the aerial part at 90 DAP and therefore less $C$ was available in the roots to maintain the mycorrhizal symbiosis. AMC and Ar were highest in roots growing in pots filled with Pasture soil followed by the Initial and Late soils (Figure 2). The lowest formation of symbiosis was detected on plants grown in the Intermediate soil. This could be probably associated with a lower $\mathrm{pH}$ than in the other sites. Soil acidity is a factor that normally affects the development of mycorrhizal symbiosis (Sieverding, 1991; BartolomeEsteban and Schenck, 1994; Fuchs and Haselwandter, 2004; Kittiworawat et al., 2010), mainly when the soil presents high $\mathrm{Al}^{+}$and $\mathrm{H}^{+}$contents, which are toxic to AMF (Porter et al., 1987) and sometimes interferes with roots colonization, because $P$ adsorption makes it unavailable to the plant. It was mentioned that highest $\mathrm{Al}^{+}$ and $\mathrm{H}^{+}$contents were found in Intermediate soils, which could explain the lowest presence of AMC in this site. However, Siqueira et al. (1990) mentioned that root colonization of Brachiaria was not greatly different between Brazilian soils of $\mathrm{pH} 4.51$ to 6.0 . But in a previous study, Siqueira et al. (1986) also showed that the ability to colonize roots grown on soil ranging in $\mathrm{pH}$ 4.5 to 6.3 was different among AMF species and that, in general, mycorrhiza formation of maize increased gradually as soil $\mathrm{pH}$ increased to $\mathrm{pH} 5$, and decreases at the highest soil $\mathrm{pH}$ of 6.3 . If in the present study the $\mathrm{pH}$ was not the cause of lower mycorrhiza formation at the Intermediate soil, it is likely that the lower amount of $C$ in roots as a consequence of the symbiosis maintenance could result in a lower plant growth This is because AMF are obligate symbionts of plants that consume photosynthates from roots (Smith and Read, 2008).

Mycorrhizal root colonization and SN of soils followed, in general, the same pattern among sites with the lowest mycorrhizal development in soils from the Intermediate area. Changing environments can induce the predominance of Intermediate-sized spores, such as in Glomus species that in general moduLate the production of spores directly according to $\mathrm{C}$ availability, showing a direct reproduction investment as expected for $r$-strategists (ljdo et al., 2010), as well as a reduction in AMF abundance and in richness species. However, Clapp et al. (1995) mentioned that AMC as well as SN could not necessarily reflect the actual AMF populations in the soils and Ahulu et al. (2006) showed that species with an abundant production of spores in the field or in the greenhouse do not always dominate the AMF community in the field roots. This could be explained because freshly formed spores can often not be readily distinguished from spores formed earlier in the season (Lee and Koske, 1994). Pianka (1970) reported that AMF that sporuLates early in trap cultures could potentially be representatives of the $r$ strategy because they could dominate resourcerich uncolonized habitats in early successional stages of the fungal community. Thus, in the present study, Glomus also seems to have shown an r-strategy and could be found also in highest proportion in soils coming 
from early and Late successional stages. Sýkorová et al. (2007) also found that some Glomus phylotypes showed an $r$-strategist behavior, rapidly colonizing ruderal habitats in early successional stages in French grasslands. They also mentioned that although AMF rstrategists typically invest heavily into their reproduction, it is possible that some of them are not prolific sporulators. The k-strategists would follow the opposite strategy showing slow growth rates under resourcelimited conditions and occurrence in Late successional areas (Pianka, 1970). In that sense because Acaulospora increased in soils coming from Intermediate and Late sites (Table 4), it probably followed a k-strategy. However, it is difficult to draw direct conclusions about the life history strategy of the AMF detected by their spores.

It is known that belowground diversity of AMF is a major factor contributing to the maintenance of plant biodiversity and to ecosystem functioning; however, the increase/decrease of $\mathrm{SN}$ with plant succession is controversial. In Brazil, Carrenho et al. (2001) developed a plant restoration study along the river Moji-Guaçu, using a mixture of pioneer, secondary (early and Late) and climax plant species. They found that the rhizosphere of pioneer species (Croton urucurana) had the lowest number of spores, and this increased progressively until the occurrence of climax species such as Genipa americana. They concluded that the number of AMF spores increases with the stage of succession. Contrarily, Zangaro et al. $(2007,2008)$ found that fastgrowing native woody species in southern Brazil showed higher levels of AMC compared to slow growing ones. The last authors suggested that the occurrence of mycorrhiza and the density of AMF spores decreased along the succession, and it could be probably due to morphological root traits in fast-growing species that favored the contact with AMF propagules in the soil. Additionally, studies by Pagano et al. $(2008,2010)$ also in semiarid fields of Minas Gerais State, showed higher mycorrhizal sporulation in disturbed sites.

In this study the highest SN was found both at Initial like (Carrenho et al., 2001) and Pasture soils and it was in accordance to the highest mycorrhizal development of roots. Moreover, it was previously showed that Braquiaria and Panicum are mycorrhizal plants (Wang and Qiu, 2006) and that AMF enhance the growth and $P$ uptake of these grasses (Siqueira et al., 1990; Roos and Allsopp, 1997).

Recently, Oehl et al. (2010) reported that soil type strongly affect AMF composition and the occurrence of many species. Our results also suggest that the physicochemical characteristics of soils influenced AMF formation more than the successional stages of the sites.

Regardless the origin and consequence of the disturbance (which sometimes can be a consequence of physicochemical differences among sites), ecosystems tend to recover naturally. It is suggested that this adaptation is mediated largely by soil microorganisms whose activity depends on the presence of indigenous AMF (Johansson et al., 2004; Artursson et al., 2006; Jin et al., 2010)

However, unexpected disruptions may occur in natural sites due to human interventions that can also accelerate natural processes of disturbance due to climatic change.

When a soil loses its natural condition (mainly by human action or when agricultural practices are installed) changes in the physical, chemical and biological soil properties undoubtedly occur. According to Lejon et al. (2005) these are the main factors controlling the transformation of organic matter and nutritional status in soils. In this sense, the monitoring of microbial populations (particularly AMF) (Pagano et al., 2011) and the physicochemical properties of soils can be useful tools to determine the state of disturbance in different sites. Studies suggest that establishment and maintenance of plant diversity in communities relies on the presence of a wide diversity of AMF (van der Heijden et al., 1998). Further, plant productivity is in general greater when a large array of AMF is associated with plants. In this regard, our results showed that Intermediate soils showed the lowest plant productivity and it was associated with the lowest mycorrhiza formation. Presumably, each AMF has a degree of specificity with hosts and it is also affected by the environment, resulting in a complex interaction whereby better combinations of fungal populations-plant-environment could contribute to plant growth and environmental sustainability. For a better understanding of the dynamics of AMF communities associated with different stages of environmental disturbance it will be necessary to classify AMF phylotypes according to their life history strategies and to monitor indigenous AMC. The present study provides the first steps in this direction. Our findings also emphasize that, in a short-term greenhouse experiment (3 month), only a certain subset of AMF genera, preferably comprising r-strategists, colonized roots of trap plants. Colonization and spore number appeared to be more reLated to soil physicochemical characteristics and host plant development than soil successional stage. However, mechanisms regulating and maintaining AMF species composition, spore density and fungus infectivity (as a measure of activity) among sites with different successional stages are not well understood. Therefore, more studies need to be aimed to identify involved mechanisms in order to ensure a successful management for the conservation and restoration of our diverse and threatened natural ecosystems.

\section{ACKNOWLEDGEMENTS}

The authors are grateful to AMFOODS Project InterAmerican Institute for Global Change Research (IAI) CRN II/14 which is supported by the US National Science Foundation (Grant GEO-04523250) INTA and CONICET- 
PIP (114201001 00252) Projects. We also thank CNPq PDJ - Brazil, for the research fellowship given to Dr. Covacevich.

\section{REFERENCES}

Ahulu EM, Gollotte A, Gianinazzi-Pearson V, Nonaka M (2006). Cooccurring plants forming distinct arbuscular mycorrhizal morphologies harbor similar AM fungal species. Mycorrhiza, 17: 3749.

Allen MF, Swenson W, Querejeta JI, Egerton-Warburton LM, Treseder KK (2003). Ecology of mycorrhizae: a conceptual framework for complex interactions among plants and fungi. Annu. Rev. Phytopathol., 41: 271-303.

Artursson V, Finlay RD, Jansson JK (2006). Interactions between arbuscular mycorrhizal fungi and bacteria and their potential for stimulating plant growth. Environmental Microbiology, 8: 1-10.

Augé R (2001). Water relations, drought and VA mycorrhizal symbiosis. Mycorrhiza, 11: 3-42.

Bartolome-Esteban H, Schenck NC (1994). Spore germination and hyphal growth of arbuscular mycorrhizal fungi in relation to soil aluminum saturation. Mycologia, 86: 217-226.

Bellgard SE, Williams SE (2011). Response of Mycorrhizal Diversity to Current Climatic Changes. Diversity, 3: 8-90.

Boerner REJ, Demars BG, Leicht PN (1996). Spatial patterns of mycorrhizal infectiveness of soils long a successional chronosequence. Mycorrhiza, 6: 79-90.

Carrenho R, Trufem SFB, Bononi VLR (2001). Fungos micorrízicos arbusculares em rizosferas de tres espécies de fitobiontes instaladas em área de mata ciliar revegetada. Acta Bot. Bras., 15: 115-124.

Clapp JP, Young JPW, Merryweather JW, Fitter AH (1995). Diversity of fungal symbionts in arbuscular mycorrhizas from a natural community. New Phytol., 130: 259-265.

Cooke JC, Buthler RH, Madole G (1993). Some observations on the vertical distribution of vesicular arbuscular mycorrhizae in roots of salt marsh grasses growing in saturated soils, Mycologia, 85: 547-550.

Covacevich F, Marino MA, Echeverria HE (2006). The phosphorus source determines the arbuscular mycorrhizal potential and the native mycorrhizal colonization of tall fescue and wheatgrass in a moderately acidic Argentinean soil. Eur. J. Soil Biol., 42: 127-138.

Covacevich F, Echeverria HE, Aguirrezabal LAN (2007). Soil available phosphorus status determines indigenous mycorrhizal colonization into field and glasshouse-grown spring wheat in Argentina. Appl. Soil Ecol., 35: 1-9.

Daniels BA, Skipper HD (1982). Methods for the recovery and quantitative estimation of propagules from soil, p. 29-35. In: Schenck NC. (ed.), Methods and principles of mycological research. The American Phytopathological Society, St. Paul., Minn.

Davies Jr FT, Potter JR, Linderman RG (1993). Drought resistance of pepper plants independent of leaf $P$ concentration response in gas exchange and water relations. Plant Physiol., 87: 45-53.

Declerck S, D'or D, Cranenbrouck S, Le Boulengé E (2001). Modelling the sporulation dynamics of arbuscular mycorrhizal fungi in monoxenic culture Mycorrhiza, 11: 225-230.

Espírito-Santo MM, Sevilha AC, Anaya FC, Barbosa R, Fernandes GW, Sanchez-Azofeifa GA, Scariot A, Noronha SE, Sampaio CA (2009). Sustainability of tropical dry forests: Two case studies in south eastern and central Brazil. For. Ecol. Manage., 258: 922-930.

Feddermann N, Roger Finlay R, Boller T, Elfstrand M (2010). Functional diversity in arbuscular mycorrhiza-the role of gene expression, phosphorous nutrition and symbiotic efficiency. Fungal Ecol., 3: 1-8.

Feng G, Zhang FS, Li XL, Tian CY, Tang C, Rengel Z (2002). Improved tolerance of maize plants to salt stress by arbuscular mycorrhiza is related to higher accumulation of soluble sugars in roots. Mycorrhiza, 12: $185-190$.

Fitter AH, Heinemeyer A, Husband R, Olsen E, Ridgway KP, Staddon PL (2004).Global environmental change and the biology of arbuscular mycorrhizas: gaps and challenges. Can. J. Bot., 82: 1133-1139.

Fuchs B, Haselwandter K (2004). Red list plants: colonization by arbuscular mycorrhizal fungi and dark septate endophytes.
Mycorrhiza, 14: 277-281.

Giovannetti M, Avio L, Fortuna P, Pellegrino E, C Sbrana, Strani $P$ (2006). At the root of the wood wide web self recognition and non-self incompatibility in mycorrhizal networks. Plant Signaling Behav., 1: 15.

Guissou T (2009). Contribution of arbuscular mycorrhizal fungi to growth and nutrient uptake by jujube and tamarind seedlings in a phosphate (P)-deficient soil. Afr. J. Microbiol. Res., 3: 297-304.

Hildebrandt U, Regvar M, Bothe H (2007). Arbuscular mycorrhiza and heavy metal tolerance. Phytochemistry, 68:139-146

ljo M, Schtickzelle N, Cranenbrouck S, Declerck S (2010). Do arbuscular mycorrhizal fungi with contrasting life-history strategies differ in their responses to repeated defoliation? FEMS Microbiol. Ecol., 72:114-122.

Jansa J, Mozafar A, Anken T, Ruh R, Sanders IR, Frossard E (2002). Diversity and structure of AMF communities as affected by tillage in a temperate soil. Mycorrhiza, 12: 225-234.

Jastrow JD, Miller RM, Lussenhop J (1998). Contributions of interacting biological mechanisms to soil aggregate stabilization in restored prairie. Soil Biol. Biochem., 30: 905-916.

Jin L, Sun X, Wang X, Shen Y, Hou F, Chang S, Wang C (2010). Synergistic interactions of arbuscular mycorrhizal fungi and rhizobia promoted the growth of Lathyrus sativus under sulphate salt stress. Symbiosis, 50: 157-164.

Johansson JF, Paul LR, Finlay RD (2004). Microbial interactions in the mycorrhizosphere and their significance for sustainable agriculture FEMS Microbiol. Ecol., 48: 1-13.

Kittiworawat S, Youpensuk S, Rerkasem B (2010). Diversity of Arbuscular Mycorrhizal fungi in Mimosa invisa and effect of the soil pH on the symbiosis. Chiang Mai J. Sci., 37: 517-527.

Lee PJ, Koske RE (1994). Gigaspora gigantea: seasonal abundance and ageing of spores in a sand dune. Mycol. Res., 98: 453-357.

Lejon DPH, Chaussod R, Ranger J, Ranjard L (2005). Microbial community structure and density different tree species in an acid forest. Microbial Ecol., 50: 614-625.

Lugo M, Cabello M (2002). Native arbuscular mycorrhizal fungi (AMF) from mountain grassland (Córdoba, Argentina) I. Seasonal variation of fungal spore diversity. Mycología, 94: 579-586.

Makoi JHJR, Ndakidemi PA (2009). The agronomic potential of vesicular-arbuscular mycorrhiza (VAM) in cereals- legume mixtures in Africa. Afr. J. Microbiol. Res., 3: 664-675.

Menéndez AB, Scervino JM, Godeas AM (2001). Arbuscular mycorrhizal populations associated with natural and cultivated vegetation on a site of Buenos Aires province, Argentina. Biol. Fertil. Soils, 33: 373-381.

Miransari M (2011). Interactions betwen arbuscular mycorrhizal fungi and soil bacteria. Appl. Microbiol. Biotechnol., 89: 917-930.

Moreira M, Baretta D, Tsai SM, Gomes-da-Costa SM, Nogueira Cardoso EJB (2007). Biodiversity and distribution of arbuscular mycorrhizal fungi in Araucaria angustifolia forest. Sci. Agric. (Piracicaba, Braz.), 64: 393-399.

Morton JB (1988). Taxonomy of VA mycorrhizal fungi: classification, nomenclature and identification. Mycotaxon, 32: 267-324.

Ndiaye F, Manga A, Diagne- Leye G, Ndiaye Samba SA, Diop TA (2009). Effects of rockphosphate and arbuscular mycorrhizal fungi on growth and nutrition of Sesbania sesban and Gliricidia sepium. Afr. J. Microbiol. Res., 3: 305-309.

Neville J, Tessier JL, Morrison I, Scarratt J, Canning B, Klironomos JN (2002). Soil depth distribution of ecto- and arbuscular mycorrhizal fungi associated with Populus tremuloides sith in a 3- year-old boreal forest clear-cut, Appl. Soil Ecol., 19: 209-216.

Newman EI (1988). Mycorrhizal links between plants: their functioning and ecological significance. Adv. Ecol. Res., 18: 243-270.

Oehl F, Sieverding E, Ineichen K, Mäder P, Boller T, Wiemken A (2003) Impact of land use intensity on the species diversity of arbuscular mycorrhizal fungi in agroecosystems of Central Europe. Appl. Environm. Microbiol., 69: 2816-2824.

Oehl F, Sieverding E, Mäder P, Dubois D, Ineichen K, Boller T, Wiemken A (2004). Impact of long-term conventional and organic farming on the diversity of arbuscular mycorrhizal fungi. Oecologia, 138: 574-583.

Oehl F, Laczko E, Bogenrieder A, K Stahr, Bösch R, van der Heijden 
M, Sieverding E (2010). Soil type and land use intensity determine the composition of arbuscular mycorrhizal fungal communities. Soil Biol. Biochem., 42: 724-738.

Omar MB, Bolland L, Heather WA (1979). P.V.A. (polyvinyl alcohol). A permanent mounting medium for fungi. Bull. Brit. Mycol. Soc., 13:3132.

Pagano MC, Cabello MN, Bellote AF, Sá NMH, Scotti MR (2008). Intercropping system of tropical leguminous species and Eucalyptus camaldulensis, inoculated with rhizobia and/or mycorrhizal fungi in semiarid Brazil. Agrofor. Syst., 74: 231-242.

Pagano MC, Cabello MN, Scotti MR (2010). Arbuscular mycorrhizal colonization and growth of Eremanthus incanus Less. in a highland field. Plant Soil Environ., 56: 412-418.

Pagano MC, Utida MK, Gomes EA, Marriel IE, Cabello MN, Scotti MR (2011). Plant-type dependent changes in arbuscular mycorrhizal communities as soil quality indicator in semi-arid Brazil. Ecol. Indicators, 11: 643-650.

Phillips JM, Hayman DS (1970). Improves procedures for clearing roots and staining parasitic and vesicular arbuscular mycorrhizal fungi for rapid assessment of infection. Trans. Br. Mycol. Soc., 55: 158-161.

Pianka E (1970). R-selection and K-selection. Am. Nat., 104: 592-597.

Pongrac $\mathrm{P}$, Vogel-Mikus $\mathrm{K}$, Kump $\mathrm{P}$, Necemer $\mathrm{M}$, Tolra $\mathrm{R}$, Poschenrieder C, Barcelo J, Regvar M (2007). Changes in elemental uptake and arbuscular mycorrhizal colonisation during the life cycle of Thlaspi praecox Wulfen. Chemosphere, 69: 1602-1609.

Porter WM, Robson AD, Abbott LK (1987). Factors controlling the distribution of VA mycorrhizal fungi in relation to soil $\mathrm{pH}$. J. Appl. Ecol., 24: 663-672.

Queiroz LP (2006). The Brazilian Caatinga: Phytogeografical patterns inferred from distribution data of the Leguminosae. In: Pennington RT, Lewis GP, Ratter JA (eds.) Neotropical Savannas and Seasonally Dry Forests. Plant Diversity, Biogeography and Conservation. CRC Press, New York, pp. 121-157.

Raviv M (2010). The use of mycorrhiza in organically-grown crops under semi arid conditions: a review of benefits, constraints and future challenges. Symbiosis, 52: 65-74.

Rillig MC (2004). Arbuscular mycorrhizae, glomalin, and soil aggregation. J. Soil Sci., 84: 355-363.

Rillig MC, Mummey DL (2006). Mycorrhizas and soil structure New Phytologist, 171: 41-53.

Roos PC, Allsopp N (1997). Soil nutrient ecology associated with Acacia sieberana at different tree densities in a South African savanna. Afr. J. Range Forage Sc., 14: 39 - 44.

SAS Copyright (c) (2002-2008) by SAS Institute Inc., Cary, NC, USA. SAS (r) Proprietary Software 9.2 (TS2M0).

Schalamuk S, Velazquez H, Chidichimo M, Cabello (2006). Fungal spore diversity of arbuscular mycorrhizal fungi associated with spring wheat: effects of tillage. Mycologia, 98: 16-22.

Schenck NC, Pérez Y (1990). Manual for the identification of VA mycorrhizal fungi, 3rd edn. Synergistic, Gainesville, Fla.

Schüßler A, Schwarzott D, Walker CA (2001). New fungal phylum, the Glomeromycota: phylogeny and evolution. Mycol. Res., 105: 14131421.

Schüßler A, Walker C (2010). The Glomeromycota: A species list with new families and new genera. Published in libraries at Royal Botanic Garden Edinburgh, Kew, Botanische Staatssammlung Munich.

Schwab S, Reeves FB (1981). The role of endomycorrhizae in Oregon State University; freely available online at www.amf-phylogeny.com revegetation practices in semi-arid west. Part III. Vertical distribution of vesicular-arbuscular (VA) mycorrhiza inoculum potential. Am. J. Bot., 68: 1293-1297.

Siddiqui ZA, Akhtar MS, Futai K (eds.) (2008). Mycorrhizae: Sustainable Agriculture and Forestry. Springer, New Delhi.

Siddiqui ZA, Pichtel J (2008). Mycorrhizae: an overview. In: Siddiqui ZA, Akhtar MS, Futai K (eds.) Mycorrhizae: Sustainable Agriculture and Forestry. Springer, New Delhi. Chapter 1.
Sieverding E (1991). Manipulation of indigenous VAM fungi through agronomic practices. In: Sieverding E (ed.) Vesicular arbuscular management in tropical agrosystems Deutsche Geseellschaft für Technische Zusammenarbeit (GTZ), Eschborn, p. 117-165

Silva Santos VL (2010). Fungos micorrízicos arbusculares em ecossistema de Mata Seca no Norte de Minas Gerais. Master dissertation Programa de Posgraduação em fitossanidade e biotecnología aplicada. Universidade Federal Rural do Rio de Janeiro, Brazil. pp. 81.

SIMGE (2008). Sistema de Meteorología e Recursos Hidricos de Minas Gerais (Brazil) http://www.simge.mg.gov.br/

Siqueira JO, Mahmud AW, Hubbell DH (1986). Differential behavior of vesicular-arbuscular mycorrhizal fungi in relation to soil acidity. $\mathrm{R}$. Bras. Ci. Solo., 10: 11-16.

Siqueira JO, Rocha WF, Oliveira E, Colozzi-Filho A (1990). The relationship between vesicular-arbuscular mycorrhiza and lime: Associated effects on the growth and nutrition of Brachiaria grass. Biol. Fertil. Soils, 10: 65-71.

Smith SE, Read DJ (eds.) (2008). Mycorrhizal Symbiosis. New York: Elsevier.

Stürmer SL (1999). Evolução, clasificação e filogenia dos fungos micorrízicos arbusculares. In: Siqueira JO, Moreira FMS, Lopes AS, Guilherme LRG, Faquin V, Furtini Neto AE, Carvalho JG (eds.). Interrelação fertilidade, biologia do solo e nutrição de plantas. Viçosa: SBCS, Lavras: UFLA, 1999. pp. 797-817.

Sýkorová Z, Ineichen K, Wiemken A, D Redecker (2007). The cultivation bias: different communities of arbuscular mycorrhizal fungi detected in roots from the field, from bait plants transplanted to the field, and from a greenhouse trap experiment. Mycorrhiza, 18: 1-14.

Tisdall JM, Smith SE, Rengasamy P (1997). Aggregation of soil by fungal hyphae. Aust. J. Soil Res., 35: 55-60.

Treseder KK, Turner KM (2007). Glomalin in Ecosystems. Soil Sci. Soc. Am. J., 71: 1257-1266.

Trotta A, Falaschi P, Cornara L, Minganti V, Fusconi A, Drava G, Berta $G$ (2006). Arbuscular mycorrhizae increase the arsenic translocation factor in the As hyperaccumulating fern Pteris vittata L. Chemosphere, 65:74-81.

Trouvelot A, Kough JL, Gianinazzi-Pearson V (1986). Mesure du taux de mycorrhization VA d'un syste'me radiculaire. Recherche de me'thodes d'estimation ayant une signification fonctionelle. In: Gianinazzi-Pearson V, Gianinazzi S (eds.). Physiological and Genetical Aspects of mycorrhiza. INRA, Paris, pp. 101-109.

Trufem SFB (1995). Aspectos ecológicos de fungos micorrízicos arbusculares na rizósfera de plantas de restinga da llha do Cardoso, SP, Brasil. Revista Brasileira de Botânica, 18: 51-60.

van der Heijden MGA, Klironomos JN, Ursic M, Moutoglis§ P, StreitwolfEngel R, Boller T, Wiemken A, Sanders IR (1998). Mycorrhizal fungal diversity determines plant biodiversity, ecosystem variability and productivity. Nature, 396: 69-72.

van der Putten WH, Bardgett RD, de Ruiter PC, Hol WHG, Meyer KM, Bezemer TM, Bradford MA, Christensen S, Eppinga MB, Fukami T, Hemerik L, Molofsky J, Schädler M, Scherber C, Strauss SY, Vos M, Wardle DA (2009). Empirical and theoretical challenges in aboveground-belowground ecology. Oecologia, 161: 1-14.

Wang B, Qiu Y-L (2006). Phylogenetic distribution and evolution of mycorrhizas in land plants. Mycorrhiza, 16: 299-363.

Zangaro W, Nishidate FR, Vandresen J, Andrade G, Nogueira MA (2007). Root mycorrhizal colonization and plant responsiveness are related to root plasticity, soil fertility and successional status of native woody species in southern Brazil. J. Trop. Ecol., 23:53-62.

Zangaro W, de Assis RL, Rostirola LV, de Souza PB, Gonçalves MC, Andrade G, Nogueira MA (2008). Changes in arbuscular mycorrhizal associations and fine root traits in sites under different plant successional phases in southern Brazil. Mycorrhiza, 19: 37-45. 